\title{
Novel green approaches towards utilization of flower waste: A review
}

Parvathi Bennurmath 的

Division of Flowers and Medicinal Crops, ICAR- Indian Institute of Horticultural Research, Bengaluru

Dipal S. Bhatt

Department of Floriculture and Landscape Architecture, ASPEE College of Horticulture and Forestry, NAU, Navsari

Anamika Gurung

Division of Flowers and Medicinal Crops, ICAR- Indian Institute of Horticultural Research, Bengaluru

Alka Singh

Department of Floriculture and Landscape Architecture, ASPEE College of Horticulture and Forestry, NAU, Navsari

S. T. Bhatt

Horticulture Polytechnics, NAU, Navsari

\begin{tabular}{|c|c|}
\hline ARTICLE INFO & ABSTRACT \\
\hline $\begin{array}{l}\text { Received : } 08 \text { May } 2021 \\
\text { Revised : } 31 \text { August } 2021 \\
\text { Accepted : } 24 \text { September } 2021 \\
\text { Available online: } 9 \text { December } 2021 \\
\text { Key Words: } \\
\text { Flower waste } \\
\text { Compost } \\
\text { Biogas } \\
\text { Natural dye } \\
\text { Essential oil and Incense sticks }\end{array}$ & $\begin{array}{l}\text { Floriculture has been associated with culture and heritage since very ancient } \\
\text { time in our country. According to Tata Energy Research Institute (TERI), the } \\
\text { waste generation rate in India is increasing at the rate of } 1.0-1.33 \text { per cent } \\
\text { annually. In most of the developing countries like India, the floral waste } \\
\text { generation occurs largely during worships, festivals, ceremonies etc. from } \\
\text { temples, mosque, flower market, flower exhibition and wedding halls find their } \\
\text { way into the garbage as a waste causing various environmental problems. This } \\
\text { paper discusses the use of solid state fermentation to convert floral wastes into } \\
\text { a variety of value-added products like as compost, biogas, bioethanol, dyes, } \\
\text { food products, biosurfactants production, incense sticks and handmade paper } \\
\text { production etc. and floral waste can thus be converted into wealth. }\end{array}$ \\
\hline
\end{tabular}

\section{Introduction}

India is on the verge of a catastrophic trash disposal problem, but solutions are not forthcoming. Traditionally, wastes have been considered nonproductive and are only managed when the need to fix the problem outweighs the practicality of disposal (Seadon, 2010). About 3,00,000 metric tonnes of flowers are being produced and utilized in India for various purposes like making garlands, decorations and ingredients in fragrances, perfumes and pigments. Flowers are a common source of floral waste since they come from hotels, wedding hall, religious venues, and numerous civilizing and holy activities. These flowers, which are offered by devotees in temples, are left unused every day and hence become waste. Degradation of floral waste is extremely slow process as compared to degradation of kitchen waste (Jadhav et al., 2013a). Significant environmental pollution results from the generation and disposal of large amounts of biodegradable waste without proper solution. According to the TATA Energy Research Institute (TERI), waste generation will exceed 260 million tonnes by 2047 , posing uncontrollable waste management challenges for metropolitan cities in the coming decades.

The Government of India has implemented a number of plans across the country, including the "Clean India Mission," which aims to control pollution and maintain a clean environment. (Elango and Govindasamy, 2018). As a result, proper and environmentally friendly floral waste treatment procedures are required. The review article here focuses on the issues surrounding floral wastes and how they can be managed by converting them into value-added products that generate wealth.

Corresponding author E-mail: parvathiflori18@gmail.com

Doi: https://doi.org/10.36953/ECJ.2021.22327

This work is licensed under Attribution-Non Commercial 4.0 International (CC BY-NC 4.0)

(C) ASEA 


\section{Problems related due to improper disposal}

In developing countries, the increasing rate of waste generation and their high collection cost are creating problems. It is estimated that in India nearly 700 million ton organic wastes is generated annually, which is either burned, or land filled (Shouche et al., 2011). About $40 \%$ of the total production of flowers are unused and wasted daily in country like Srilanka and India (Masure and Patil., 2014). These flowers are directly thrown into water covered by plastic or dumped on land, causing problems such as water and land pollution, development of eels and worms, the production of leachate and a foul odour. (Wijayapala, 2013). In India, approximately $8,000,000 \mathrm{t}$ of flower waste are dumped into rivers each year, choking them to death. Pesticides and chemical fertilizers used in cultivation mix with river water, making it highly toxic and polluting soil fertility, lowering the land's aesthetic value. Toxic gases are released into the atmosphere when waste flowers are not completely burned.

\section{Approaches in utilization of flower waste: Value} added products

Vermicompost, biofuels, bioethanol, pigments, dyes, food products, biosurfactants manufacture, incense sticks, handmade paper manufacture and other value-added items can all benefit from solid state fermentation.

\section{Vermicomposting}

This method can be successfully utilized in temples as a solid waste management strategy with flowers as the major organic waste which will help by reducing volume of temple waste and at the same time generate additional revenue for the temples and can also be used as an alternative to chemical fertilizers to enhance the growth and yield of various plants. The temple waste from the Ganesh temple in Sangli, Maharashtra, was combined with the biogas digester effluent. The optimum parameters for vermicomposting were found to be temperature $\left(25^{\circ} \mathrm{C}\right), \mathrm{pH}(8.0)$, particle size (1$2 \mathrm{~mm})$ and moisture content $(80 \%)$ with percent carbon, nitrogen, phosphorus and potassium content of $28,1.58,0.33$, and 0.28 , respectively. They have also done the pot culture studies using five flowering plants (Gulab, Jaswand and Mogra varieties) of the test set (using prepared vermicompost as fertilizer) used in the studies showed good improvement of growth in terms of height, flowering time as well as number of flowers produced as compared to control sets (without use of vermicompost as fertilizer) (Gaurav and Pathade, 2011). Similarly, $20-30^{\circ} \mathrm{C}$ temperature, $\mathrm{pH}$ 6-8 and $60-70 \%$ moisture content were optimum during vermicomposting as illustrated in a study by Shouche et al., 2011. Vermicomposting contains plant hormones like auxin and gibberellins and enzymes which can encourage plant growth and discouraged plant pathogens (Sailaja et al., 2013). The Pleurotus species were very effective to remove the dyes from the waste woody material used in dry flower industries in Thoothukudi and for decomposition to produce cost-effective compost (Siluvai and Kirubagari, 2014). Temple waste was utilized as a potential resource material for E. fetida biomass and vermicompost production and showed variation in growth parameters of chickpea by enhancing root length, shoot length, number of secondary roots and total biomass at $12.5 \%$ VC compared to Kitchen waste and Farm yard manure vermicompost (Singh et al., 2013). Similarly, Pot culture experiment was conducted with Solanum lycopersicum L. and showed good enhancement of growth (Jain, 2016). Jadhav et al., $2013 \mathrm{~b}$ have used flower waste generated from temples for degradation using microbial consortium Flower waste was collected and isolated with selected soil samples. The microbial consortia improved waste digestion and of good quality without harming the environment and the degraded material had high $\mathrm{N}, \mathrm{P}$, and $\mathrm{K}$ content, making it suitable for use as a nitrogen potash biofertilizer. In a study, marigold flower waste was mixed with cow dung in different proportions and Eisenia foetida was introduced. The bioconversion ratio, or the proportion of waste to vermicompost, was found to be high (60:40), and the amount of organic carbon, phosphorus and potassium vermicompost samples for all groups was higher than in control samples (without worms). It was observed that mixing floral waste with cow dung in 50:50, 60:40, and 70:30 ratios could produce nutrient-dense vermicompost. (Tiwari and Juneja, 2016)

\section{Bio-gas generation}

When compared to other waste treatment technologies, anaerobic digestion has the following advantages: low sludge output, cheap cost, great energy efficiency, and process simplicity. Furthermore, because it combines waste 
stabilisation with net fuel generation and permits the effluent to be used as fertilizer and also for electricity generation, it has a beneficial environmental impact (Patel and Madamwar, 2001). Shri Mahakaleshwar temple produces around 3 tonnes of flower waste. therefore this technology is developed to generate energy (Agarwal, 2011). Singh and Bajpai (2012) studied on anaerobic digestion for methane production from flower waste and resulted that the process of digestion eliminated the pollution effects and removed pollutants like BOD and TS. During winter season (December to February), the biogas production of methane and carbon dioxide was $43 \%-50 \%, 44 \%-50 \%$, respectively whereas $50 \%$ $54 \%$ of methane and $40 \%-43 \%$ of carbon dioxide produced during summer season (March to May). Biogas production of Rose residue by anaerobic digestion were studied in a batch reactor and the process removed up to $73 \%, 82 \%, 45 \%, 42 \%, 58 \%$ of total solids, chlorides, volatile solids, Biochemical Oxygen Demand, Total Kjeldhal Nitrogen respectively, along with biogas production (Kumar and Swapnavahini, 2012). Prasad (2014) worked on utilization of flower waste by anaerobic decomposition process using lab scale model found that $60 \%$ consisting of methane and the pressure fall from $10 \%$ of flower waste with cowdung showed increase in pressure upto $0.44 \mathrm{Kg} / \mathrm{cm} 2$. Anaerobic digestion of flowers (jasmine, sunset flower, Roselle, African wattle, Nile tulip flower, silk tree mimosa) and vegetable wastes (brinjal, cabbage, carrot, ladies finger) in a $1 \mathrm{~L}$ capacity anaerobic digestor utilising cow dung as inoculums was studied in the laboratory. At room temperature, the digester was run in a 1:1 substrate to inoculums ratio, revealed that flowers had produced higher yield of biogas $(16.69 \mathrm{~g} / \mathrm{kg}$ in 4.5 days $)$ than vegetable wastes $(9.089 \mathrm{~g} / \mathrm{kg}$ in 6 days) (Ranjitha et al., 2014).

\section{Natural Dye}

Due to the harmful effects and allergic reactions connected with synthetic dyes, people are becoming more aware of the benefits of utilizing natural dyes., Teli et al (2013) studied to isolate natural dyes from hibiscus and marigold flowers and with the help of different natural mordents like alum, harad and ferrous sulphate showed a very good potential to dye on cotton and cotton/silk blended fabric. Because of their eco friendliness, low cost of manufacturing and easy waste management, natural dyes derived from rose residue have a wide range of commercial applications in dye-sensitized solar cells (Eren et al., 2015). In a study, making dyes for cotton, wool and silk on industrial scale reported that pretreatment with $1-2 \%$ of metal mordant and $5 \%$ of plant extract was found to be satisfactory for marigold petals (Vankar et al., 2009). Similarly, for bleached cotton fabrics, pretreatment with 1-2 percent metal mordant and 5\% plant extract was reported to be optimal and showed excellent fastness properties and observed orange coloured calyx as main colour yielding part in the Sepalika (Nyctanthes arbor-tristis) flower waste (Wijayapala, 2013). The saffron flower waste was used for extraction of natural dye produced bright greenish yellow and green colour on pashmina fabric at acidic $\mathrm{pH}$ and also found that the fabric dyed at acidic $\mathrm{pH}$ without mordant has antimicrobial efficiency against Staphylococcus aureus (Raja et al., 2012). The maximum quantity of colour extraction was observed at low temperatures of $75^{\circ} \mathrm{C}$ to $85^{\circ} \mathrm{C}$ with low quality, whereas the minimum quantity of colour was noticed at high temperatures of $90^{\circ} \mathrm{C}$ to $95^{\circ} \mathrm{C}$ with good quality colour, and the minimum time necessary to extract excellent quality colour for rose petals was 15 minutes and 25 minutes for marigold petals at $90^{\circ} \mathrm{C}$ as illustrated by Masure and Patil, 2014. Jadhao and Rathod, 2013 worked on the extraction of patuletin dye from French marigold flower waste generated from temple and they found that the high antioxidant capacity than base and below the catechol was observed in patuletin dye wherein in industries it is thrown to river generally and reported that as compared to catechol, the patuletin dye is easily degradable, low cost and has no hazardous effect.

\section{Essential Oil}

The flowers which were offered to deities in temples were available around 1450 tonnes as temple waste among this rose recorded as $50 \%$. Steam distillation was used to obtain rose oil $(0.14$ $\%)$ from the offered temple flower Rosa damascene. GC-MS analysis was used to analyse the chemical components present in rose oil, yielding 54 compounds, the most prominent of which was phenyl ethyl alcohol (23.19 percent) 
followed by octadecane $(10.49 \%)$, hexadecane (7.76\%), phenyl ethyl tetra decyl ester $(5.77 \%)$ and tetra methyl trisiloc endecanol (3.45\%) (Perumal et al., 2012).

\section{Incense Sticks and Rose Water}

Through the use of science and technology, the 'Mission Sakshama' initiative, established by CSIR's flagship institute Central Institute of Medicinal and Aromatic Plants (CIMAP), Lucknow, has opened the way to empower rural women in Lucknow while simultaneously mitigating pollution in the area. In Ajmer, with technical assistance from CIMAP, the Sharif Dargah committee has installed a rose water distillation plant at the outskirts of Ajmer to extract rose water from offered flowers (Indian Express, May, 2010). Incense sticks are made from flowers such as genda (Tagetes). According to the institute, this method can produce 1,500 agarbattis (incense) from one $\mathrm{kg}$ of raw material (filling material like flower powder and binding material). (The Hindu, Jan 25, 2013).

\section{Biosorption Studies}

Heavy metals are extensively used in industries like batteries, electroplating, steel works, paint pigments, electrical accumulators etc. These metals are generally disposed of in water because they cannot be degraded biologically into innocuous compounds. Biosorption is a promising method for removing heavy metal ions that makes use of lowcost biosorbents. (Fourest and Roux, 1992). By treating the red rose biomass with methanol and polyethyleneimine + glutraldehyde, researchers were able to extract heavy metals from aqueous solutions with a maximum biosorption capacity of
99.72 and $51.68 \mathrm{mg} / \mathrm{g}$ for $\mathrm{Pb}(\mathrm{II})$ and $\mathrm{Co}(\mathrm{II})$, respectively (Haq et al., 2011).

Table 1: Floral waste used in biosorption experiments (Waghmode et al., 2018)

\begin{tabular}{|c|c|c|}
\hline $\begin{array}{l}\text { Source } \\
\text { material }\end{array}$ & Application & Bibliography \\
\hline Red rose & $\begin{array}{l}\text { Biosorption of } \\
\mathrm{Co}(\mathrm{II}) \\
\mathrm{Pb}(\mathrm{II})\end{array}$ & $\begin{array}{l}\text { HAQ et al. } \\
(2011)\end{array}$ \\
\hline $\begin{array}{l}\text { Carnation, } \\
\text { Daisy and } \\
\text { Rose }\end{array}$ & $\begin{array}{l}\text { Biosorption of } \\
\text { acid blue } 9\end{array}$ & $\begin{array}{l}\text { Echavarria- } \\
\text { Alvarez and } \\
\text { Hormaza } \\
\text { Anaguano (2014) }\end{array}$ \\
\hline $\begin{array}{l}\text { Biomass } \\
\text { derived after } \\
\text { color } \\
\text { extraction of } \\
\text { Hibiscus, } \\
\text { Portulaca and } \\
\text { Canna }\end{array}$ & $\begin{array}{l}\text { Removal of } \\
\text { chromium from } \\
\text { aqueous phase }\end{array}$ & $\begin{array}{l}\text { Vankar et al. } \\
(2010)\end{array}$ \\
\hline
\end{tabular}

\section{Valorization}

Slavov et al., 2013 reported that the distilled rose petals as a source of immunomodulating pectic polysaccharides produced water-soluble polysaccharide. A combination strategy for the recovery of biologically active chemicals from waste rose biomass included the sequential extraction of polyphenols and pectin polysaccharides and the waste rose biomass could be a rich source of biologically active compounds, according to the overall yield of polysaccharides (25.3\%) and polyphenols (4.4\%) (Slavov et al., 2017).

Table 2: Technologies available at various institutes

\begin{tabular}{|c|c|c|c|}
\hline SN & Technologies Available & Product/Process & Institute \\
\hline 1 & For flower waste utilizarion & Incense sticks & CIMAP, Lucknow \\
\hline 2 & Dehydration of flowers and foliage & $\begin{array}{l}\text { greeting cards, wall plates, } \\
\text { landscapes, three dimensional } \\
\text { decorative items, etc. }\end{array}$ & NBRI, Lucknow \\
\hline 3 & $\begin{array}{l}\text { Eco-friendly dyeing and antibacterial } \\
\text { finishing of soya bean protein fabric } \\
\text { using temple flower waste. }\end{array}$ & Natural dye & $\begin{array}{l}\text { Institute of Chemical } \\
\text { Technology, Mumbai }\end{array}$ \\
\hline 4 & Vermicomposting & $\begin{array}{l}\text { Production of vermicompost from } \\
\text { temple waste }\end{array}$ & $\begin{array}{l}\text { K. W. College, Sangli, and } \\
\text { Fergusson } \\
\text { Maharashtra }\end{array}$ \\
\hline 5 & $\begin{array}{l}\text { Utilization of temple flower waste for } \\
\text { dyeing of Cotton, Wool and Silk on } \\
\text { industrial scale }\end{array}$ & Natural dye & IIT, Kanpur \\
\hline
\end{tabular}




\section{Conclusion}

The significance of bioremediation of floral wastes is of high importance. In addition to trash, temple waste flowers have a noteworthy impact on the environment and human health. The article discusses the floral waste management by converting them into various value-added products,

\section{References}

Agarwal, S. (2011). Report on demonstration of renewable energy system at Shri Mahakaleshwar Temple Complex in Ujjain. Ministry of new and renewable energy, New Delhi, pp1-4.

Echavarria-Alvarez, A. M., \& Hormaza-Anaguano, A. (2014). Flower wastes as a low-cost adsorbent for the removal of acid blue 9. Dyna, 81(185), 132-138.

Eren, E., Gok, E. F., Seyhan, B. N., Maslakci, N. N., \& Oksuz, A. U. (2015). Evaluation of anthocyanin, a rose residue extract, for use in dye-sensitized solar cell. Asian Journal of Chemistry, 27(10), 3745-3748.

Fourest, E., \& Roux, J. C. (1992). Heavy metal biosorption by fungal mycelial by-products: mechanisms and influence of pH. Applied microbiology and biotechnology, 37(3), 399403.

Haq, N. B., Rubina, K., \& Muhammad, A. H. (2011) Biosorption of $\mathrm{Pb}$ (II) and $\mathrm{Co}$ (II) on red rose waste biomass.

Jadhao, N. U., \& Rathod, S. P. (2013). The extraction process and antioxidant properties of patuletin dye from wasted temple French marigold flower. Asian Journal of Plant Sciences \& Research, 3, 127-132.

Jadhav, A. R., Chitanand, M. P., \& Shete, H. G. (2013). Flower waste degradation using microbial consortium. IOSR Journal of Agriculture and Veterinary Science, 3(5), 1-63.

Jain, N. (2016). Waste management of temple floral offerings by vermicomposting and its effect on soil and plant growth. International Journal of Environmental \& Agriculture Research, 2(7), 89-94.

Kumar, M., \& Swapnavahini, K. (2012). Nutrient reduction and biogas production of rose residue by anaerobic digestion in a batch reactor. Int $J$ Adv Res $S c i$ Technol, 1(2), 125-129.

Masure, P. S., \& Patil, B. M. (2014). Extraction of W aste Flowers. Int. J. Eng. Res. Technol., 3, 43-44.

Patel, H., \& Madamwar, D. (2001). Single and multichamber fixed film anaerobic reactors for biomethanation of acidic petrochemical wastewater-systems performance. Process Biochemistry, 36(7), 613-619. including as compost for plant development, biogas for energy generation, and dyes and pigments in the textile industry while, biofuels and bioethanol could solve the problem of energy crisis. This will solve the problem of floral waste disposal, and as a result, water and environmental pollution will be reduced, and waste will be converted to wealth.

Perumal, K., Moorthy, T. S., \& Savitha, J. S. (2012). Characterization of essential oil from offered temple flower Rosa damascena Mill. Asian Journal of Experimental Biological Sciences, 3(2), 330-334.

Prasad, (2014). Production and utilization of flower waste by anaerobic decomposition process. Project reference no. 38s1468, SJB Institute of Technology, Bengaluru.

Raja, A. S. M., Pareek, P. K., Shakyawar, D. B., Wani, S. A., Nehvi, F. A., \& Sofi, A. H. (2012). Extraction of Nat-ural Dye from Saf-fron Flower Waste and its Applica-tion on Pashmina fabric.

Ranjitha, J., \& Vijayalakshmi, S. (2014). Production of bio-gas from flowers and vegetable wastes using anaerobic digestion.

Sailaja, D., Srilakshmi, P., Shehanaaz, P. H., Bharathi, D. L., \& Begum, A. (2013). Preparation of vermicompost from temple waste flower. Int J Sci Inno Discov, 3(3), 367-375.

Seadon, J. K. (2010). Sustainable Waste Management Systems. Journal of Cleaner Production, (18), 1649-1651.

Shouche, S., Pandey, A., \& Bhati, P. (2011). Study about the changes in physical parameters during vermicomposting of floral wastes. Journal of environmental research and development, 6(1), 63-68.

Siluvai, C., \& Kirubagari, A. (2014). Fungal degradation of dry flower industrial waste and evaluation of dye level by HPLC. Journal of Microbiology and Biotechnology Research, 4(3), 40-50.

Singh, A., Jain, A., Sarma, B. K., Abhilash, P. C., \& Singh, H. B. (2013). Solid waste management of temple floral offerings by vermicomposting using Eisenia fetida. Waste management, 33(5), 1113-1118.

Singh, P., \& Bajpai, U. (2012). Anaerobic digestion of flower waste for methane production: an alternative energy source. Environmental Progress \& Sustainable Energy, 31(4), 637-641.

Slavov, A., Denev, P., Panchev, I., Shikov, V., Nenov, N., Yantcheva, N., \& Vasileva, I. (2017). Combined recovery of polysaccharides and polyphenols from Rosa damascena wastes. Industrial Crops and Products, 100, 85-94. 
Slavov, A., Kiyohara, H., \& Yamada, H. (2013). Immunomodulating pectic polysaccharides from waste rose petals of Rosa damascena Mill. International journal of biological macromolecules, 59, 192-200.

Teli, M. D., Valia, S. P., \& Kolambkar, D. (2013). Flower waste from temple for dyeing of cotton and cotton/silk. $J$ Textile Assoc, 74(4), 210-214.

Vankar, P. S. (2009). Utilization of Temple waste flowerTagetus erecta for Dyeing of Cotton, Wool and Silk on Industrial scale. Journal of textile and Apparel, Technology and Management, $6(1)$
Vankar, P. S., Sarswat, R., \& Malik, D. S. (2010). Biosorption of lead and cadmium ions from aqueous solutions onto natural dye waste of Hibiscus rosa sinensis. Environmental Progress \& Sustainable Energy, 29(4), 421-427.

Waghmode, M. S., Gunjal, A. B., Nawani, N. N., \& Patil, N. N. (2018). Management of floral waste by conversion to value-added products and their other applications. Waste and Biomass Valorization, 9(1), 33-43.

Wijayapala, S. (2013). Utilisation of Sepalika (Nyctanthes arbor-tristis) Flowers, a Temple Waste as a Source for a Potential Colouring Agent for Textile Substrates Used in the Textile Industry. In Proceedings of International Forestry and Environment Symposium (Vol. 18). 